\title{
Effects of recurrent disturbances on the periphyton community downstream of a dammed watercourse
}

\author{
Zanon, JE.*, Simões, NR. and Rodrigues, L. \\ Postgraduate course in Ecology of Continental Aquatic Environments - PEA, Department of Biology, \\ Maringa State University - UEM, Av. Colombo, 5790, CEP 87020-900, Maringá, PR, Brazil \\ *e-mail: jaques.zanon@gmail.com
}

Received April 12, 2012 - Accepted June 15, 2012 - Distributed May 31, 2013

(With 5 figures)

\begin{abstract}
We evaluate experimentally the effect of a sequential disturbance—desiccation—on the structure and dynamics of a periphytic algal community in a semilotic environment of the Upper Paraná River floodplain. We tested the hypothesis that the presence of recurrent disturbances have a direct negative effect on the attributes of the periphyton community. The sequential effect of desiccation on the periphytic community promoted its significant decrease in density, while the same was not observed in species richness. When desiccation was induced in a mature community, there was no difference in the community compared to control. The sequential disturbances on the community of periphytic algae in a mature stage, was characterised by greater stability. It is believed that the effects of variation in water levels caused by upstream reservoirs can likewise also modify the structure and stability of periphytic algae in the Upper Paraná River floodplain.
\end{abstract}

Keywords: disturbance, periphyton, desiccation, stability, floodplain.

\section{Efeitos de distúrbios sequenciais na comunidade perifítica à jusante de um curso de água represado}

\begin{abstract}
Resumo
Avaliou-se experimentalmente o efeito de distúrbios sequenciais - dessecamento - na estrutura e na dinâmica da comunidade de algas perifíticas em um ambiente semilótico da Planície de Inundação do Alto Rio Paraná. Testou-se a hipótese de que a presença de distúrbios recorrentes tem efeito negativo direto nos atributos da comunidade de algas perifíticas. O efeito sequencial do dessecamento sobre a comunidade perifítica promoveu o decréscimo significativo da sua densidade, enquanto que, em relação à riqueza de espécies, o mesmo não foi observado. Quando o dessecamento foi aplicado em uma comunidade madura, em processo avançado de desenvolvimento, não houve diferença na comunidade em relação ao controle. As perturbações sequenciais sobre a comunidade de algas perifíticas em um estágio maduro foi caracterizada por maior estabilidade. Acredita-se que os efeitos da variação do nível da água, causada por reservatórios a montante, podem, do mesmo modo, também modificar a estrutura e a estabilidade de algas perifíticas na Planície de Inundação do Alto Rio Paraná.
\end{abstract}

Palavras-chave: distúrbio, perifíton, dessecamento, estabilidade, planície de inundação.

\section{Introduction}

The hydrological regime is considered to be the key factor driving ecological functioning and biodiversity patterns in river floodplain systems (RFSs) (Junk et al., 1989; Neiff, 1990; Bunn and Arthington, 2002). Dammed watercourses have a hydrological regime that is artificially controlled by the dams, which work as discharge regulators. Flooding occurs only when the reservoir has reached its absolute maximum, and low discharges will only reoccur during long-term dry periods, or in the case of problems in the generation/consumption energy balance (Souza Filho et al., 2004).
This results in a highly variable flow regime, with abrupt changes that can spread several kilometers downstream until they are ameliorated (Petts, 1984), but which can still vary throughout the day, week or season of the year (Poff et al., 1997; Agostinho et al., 2007). The variation in the river's water level can achieve daily differences of between $20 \mathrm{~cm}$ to over one metre between morning and early evening (Souza Filho et al., 2004). This can cause partial exposure or, in extreme cases, total exposure of the riverbed downstream, creating a major impact on the resident ecological communities by exposing them 
to desiccation. This process has a direct effect on littoral communities including the periphyton community.

As a physical disturbance, desiccation can cause significant effects on the function and structure of periphyton communities (Peterson, 1996). In fact, Biggs (1996) notes that periphyton can be directly affected through disturbance rather than other processes.

According to Agostinho et al. (2004), changes in the hydrological regime of floodplain rivers affect the physical and biological environments, constituting one of the most serious threats to the biotic integrity of the system, by direct or indirect interference with the structure of habitats, communities, and other functional aspects of the environment. These changes influence the structure and distribution of the various communities living in the floodplain, including the periphytic algal community which is commonly studied in these ecosystems (Gottlieb et al., 2006; Luttenton and Baisden, 2006; Davidson et al., 2012; Mihaljević and Pfeiffer, 2012)

As the key factor, the intensity and frequency of the flood pulses also influence a series of other important factors that affect the structure of the periphytic algal community in the Upper Paraná River floodplain. These factors include the availability of propagules (Rodrigues and Bicudo, 2001), nutrient concentration (Murakami and Rodrigues, 2009), primary production (i.e. biomass) (Leandrini et al., 2008; Leandrini and Rodrigues, 2008), taxonomic composition (Algarte et al., 2009; Rodrigues and Bicudo, 2001) and density of organisms (Fonseca and Rodrigues, 2005). Additionally, Rodrigues and Bicudo (2001) suggest the importance of physical disturbances in this system.

The response of the periphytic community to desiccation varies according to various factors, including how thin the biofilm is, the taxonomic composition and production of external mucilage (Hawes et al., 1992; Blinn et al., 1995; Stanley et al., 2004; Mcknight et al., 2007; Ledger et al., 2008). This study aimed at verifying the effect of sequential disturbances - experimental simulations of desiccation - on the structure and dynamics of the periphytic algal community during its process of colonisation and succession in the Upper Paraná River floodplain. We tested the hypothesis that a large number of desiccation disturbances produced by the daily variation of water level have a direct negative effect on the attributes of the periphytic community.

\section{Material and Methods}

The experiment was set up in Pau Veio Backwater (see Figure 1) which is directly connected to the Paraná River, one of the most regulated river stretches in the world (more than 46 large dams) (Agostinho et al., 2007), in the Upper Paraná River floodplain (22 44' 50.76" S and $53^{\circ}$ 15 ' 11.16" W). A wooden support containing removable

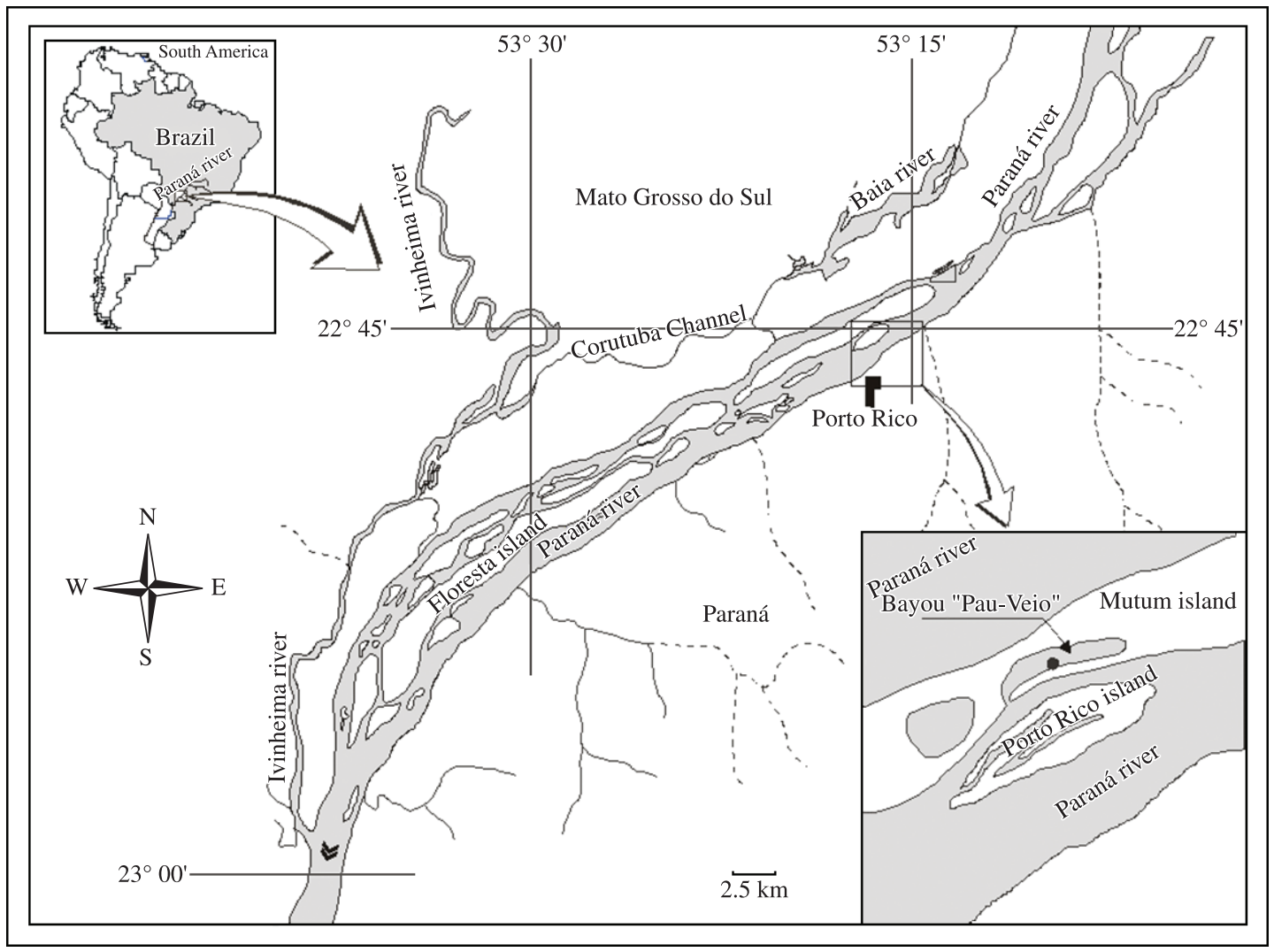

Figure 1. Location of the Pau Veio Backwater in the Upper Paraná River floodplain. 
drawers that held glass slides was placed on the littoral zone of the backwater for colonisation, next to stands of Eichhornia azurea Kunth.

Daily changes in water level, prompted by the dams upstream, expose, for a short period of time (about 12 to 15 hours), the banks of floodplain lakes. To simulate this disturbance on periphytic communities, we removed from the water a given drawer and transferred it ashore, returning it after 12 to 15 hours, increasing the number of drawers removed throughout the experiment (as shown in Figure 2). Some supports were kept constantly in the aquatic environment as a control treatment, with no induced desiccation disturbance. The glass slides were randomly collected in each respective drawer at the same depth.

As described above, the control treatment (0D) did not experience any desiccation disturbance at any time; the treatment which experienced weak disturbance (1Dd) was subjected to desiccation (15 hours) at 20 days (d) of the community's development; the treatment which experienced medium disturbance (2Dd) was subjected to desiccation at 15 days (1Dc) and 20 days (2Dd); the treatment which experienced high disturbance (3Dd) was subjected to desiccation at 10 days (1Db), 15 days (2Dc) and 20 days ( $3 \mathrm{Dd}$ ); the treatment which experienced very high disturbance (4Dd) was subjected to desiccation at 5 days (1Da), 10 days (2Db), 15 days (3Dc) and 20 days (4Dd). This procedure, illustrated in Figure 2, allowed us to compare communities that suffered all disturbances at the end of 20 days.

The glass slides were randomly collected in replicate ( $n=2$ glass slides) for the quantitative analyses and transported in a humid chamber. These were maintained on ice until scraping of the periphytic material, which was performed with the aid of a steel blade and distilled water jets. The samples were put into $150 \mathrm{~mL}$ glass containers, fixed and preserved in a solution of acetic Lugol (5\%), according to Bicudo and Menezes (2006).

The taxa quantification were carried out with an inverted microscope (Olympus ${ }^{\circledR}$ CK2), using sedimentation chambers according to the method of Utermöhl (1958), and through random fields as recommended by Bicudo (1990). Counting was performed until at least 100 individuals of the predominant taxa had been identified, as well as stabilisation of the cumulative species curve. The equation for calculating the density followed Ros (1979), adapted to the substrate area, and the results were expressed per unit area (individuals $\times \mathrm{cm}^{-2}$ ). The qualitative analysis was based on quantitative data of periphytic algae.

The analysis of the structure of epiphytic algal community was performed using the following descriptors: richness expressed as the number of taxa, and density following the taxa quantification method. The differences among the mean values of these attributes between the treatments were analysed using an analysis of variance (ANOVA-one way analysis).

The community structure over time for the different disturbance levels was represented by means of a nonmetric multidimensional scaling (NMDS), employing the Bray-Curtis dissimilarity (Clarke and Warwick, 2001). Distortion of the two-dimensional data resolution was expressed by the value of S (stress). The closer to zero is the stress value, the better the fitness between the original

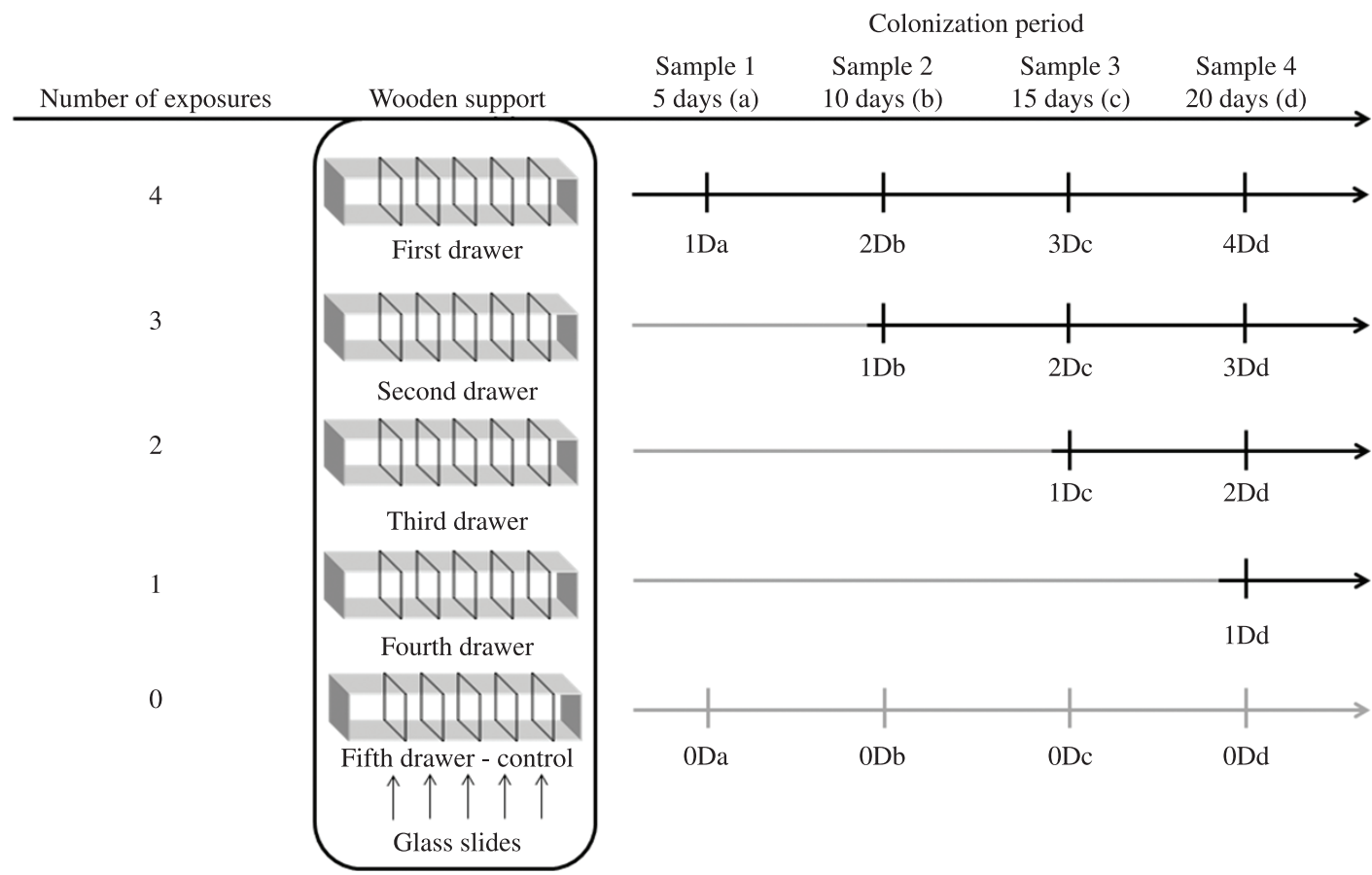

Figure 2. Representation of the treatments (drawers) subjected to the disturbances. (Grey line: no disturbances experienced. Black line: disturbances experienced. $A=5$ days, $b=10$ days, $c=15$ days and $d=20$ days, $D=$ Induced disturbance). 
distance of the sampling data and the configuration obtained by analysis (Legendre and Legendre, 1998). For this, we used the program PAST version 2.08 (Hammer et al., 2001).

\section{Results}

Based on quantitative data, 168 taxa were identified and distributed into the classes: Zygnemaphyceae (49 taxa), Bacillariophyceae (46), Chlorophyceae (29), Cyanophyceae (20), Euglenophyceae (13), Oedogoniophyceae (6), Xanthophyceae (4) and Rhodophyceae (1). The total species richness for the final colonisation period $(\mathrm{d}=21$ days) was not significantly different $\left(\mathrm{F}_{(4,7)=} 1.7178, \mathrm{p}=0.2496\right)$, but a drop in species numbers was observed as disturbances accumulated (see Figure 3).

Unlike species richness, species density significantly decreased as disturbances accumulated (see Figure 4), highlighting the three disturbances (3Dd) and four disturbances (4Dd) treatments.

The most abundant class was Bacillariophyceae, followed by Zygnemaphyceae, Chlorophyceae, Cyanophyceae and Oedogoniophyceae. The classes Euglenophyceae,

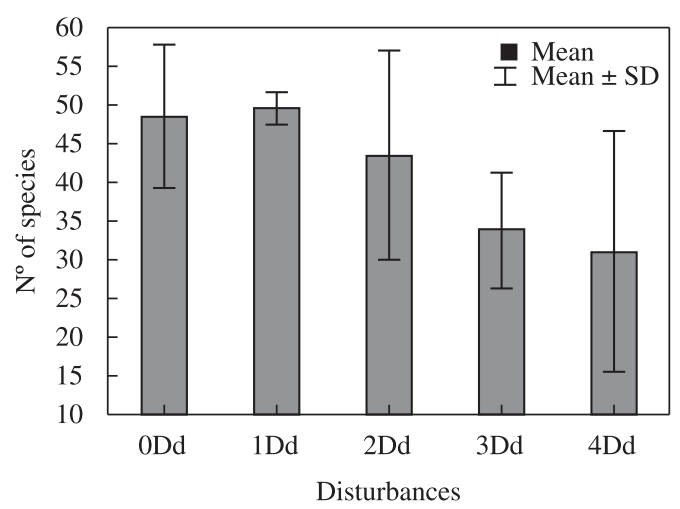

Figure 3. Richness of periphytic algae in face of the accumulation of disturbances at the final colonisation period in the treatments studied in Pau Veio Backwater, Upper Paraná River floodplain.

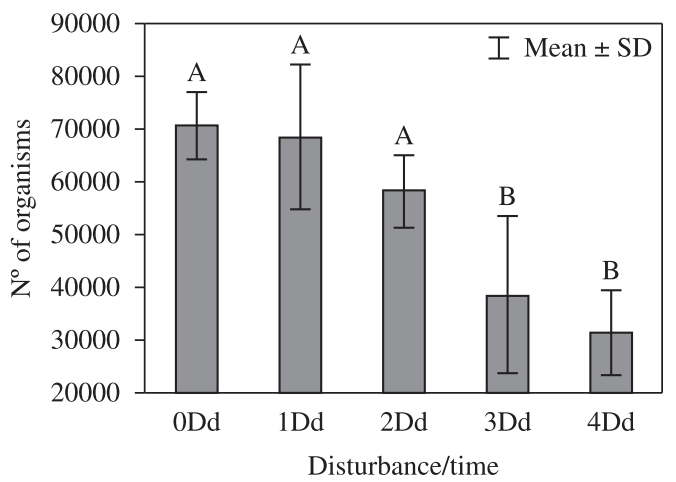

Figure 4. Density of periphytic algae in face of the accumulation of disturbances at the $20^{\text {th }}$ day in Pau Veio Backwater, Upper Paraná River floodplain $\left(\mathrm{F}_{(4 ; 7)}=4.9794\right.$; $\mathrm{p}=0.0322$ ).
Xanthophyceae and Rhodophyceae presented lower abundances.

Non-metric multidimensional scaling (NMDS) provided evidence of a separation between communities of the control treatment (ODa, ODb, ODc and ODd) and those subjected to a greater amount of disturbance (4Dd) (see Figure 5). The periphytic community subjected to only one disturbance at the beginning of the colonisation process (1Da and $1 \mathrm{Db}$ ) was more similar to the control. There was a lower structural variation as the disturbances occurred on the more mature community in an advanced stage of development (Dc and Dd). At the end of the experiment, a greater dissimilarity was detected between the community subjected to no disturbance (ODd) and that subjected to four disturbances (4Dd) (see Figure 5).

\section{Discussion}

The sequential effect of desiccation significantly reduced the density of the periphytic algal community. Such type of physical disturbance can affect the structure and productivity of the algal community (Gottlieb et al., 2005). This demonstrates that recurrent events since the start of colonisation promoted the removal of algae near the surface of the biofilm which had not yet been embedded in the matrix.

Pickett and White (1985) recognise that disturbance frequency, defined by the number of events over time, affects the ecosystem response. The more frequent the disturbance, the lower the potential for recovery of intolerant organisms (Collins et al., 2001). This, in turn, may destabilise the community dynamics and increase system variability (Collins et al., 2001). Furthermore, Robinson et al. (2004) discusses in his experimental study the cumulative effects of floods.

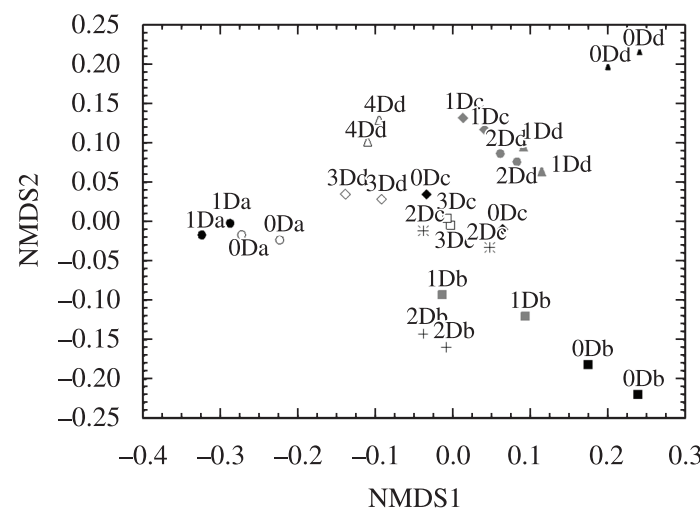

Figure 5. Non-metric multidimensional scaling used for the analysis of the structure of periphytic algae found in Pau Veio Backwater, Upper Paraná River floodplain $(S=0.1911$, 0D: control treatment; 1D: treatment subjected to only one disturbance; 2D: treatment subjected to two disturbances; 3D: treatment subjected to three disturbances; 4D: treatment subjected to four disturbances. $\mathrm{a}=5$ days, $\mathrm{b}=10$ days, $\mathrm{c}=15$ days and $\mathrm{d}=20$ days). 
Disturbances also play an important role on species diversity and composition by changing environmental resources, creating opportunities for some species and eliminating others. The "intermediate disturbance hypothesis" suggests that species diversity should be higher at moderate levels of disturbance (Connell, 1978). Under conditions of recurrent disturbance, biological diversity can adapt, with the result that it becomes dependent on these disturbances for the organisation and behaviour of species in the community (Hobbs and Huenneke, 1992).

In advanced stages of succession, species composition of the periphyton subjected to low and medium disturbance was very similar, having little change in the control treatment, with the most similar being 2Dd, $1 \mathrm{Dc}$ and $1 \mathrm{Dd}$. In this case, the mucilage of a biofilm at mature state may have favoured the permanence of a greater number of species, as the extracellular polysaccharides produced by the algae in the form of mucilage have multiple functions, one of which is to increase resistance to desiccation (Hoagland et al., 1993). Furthermore, Peterson (1987) suggests that the production of mucilage provides an increased resistance to repeated desiccation, mainly in Cyanobacteria (Potts, 1999).

Periphytic algae had no significant reduction in species richness $(\mathrm{F}=1.7178, \mathrm{p}=0.2496)$, conferring to the community a stability in the face of the applied disturbances. According to McCormick (1996) disturbances typically result in disproportionate losses in populations of those species that are competitively dominant within the mat. Selective removal of competitive dominants enhances the potential for species coexistence and, consequently, habitats exposed to disturbance tend to exhibit higher species richness than comparable habitats that are undisturbed. This relation between species richness and disturbance could explain the non-significance of species richness loss. Moreover, according to Peterson (1996) physical disturbance can favour periphyton, since the surface is removed, permitting the entry of nutrients and the renewal of the community.

The cumulative desiccation events worked as disturbances for the periphytic algal community, changing its structure and dynamics. These events may limit the community to remaining in its initial development stage condition. It is believed that the effects of the variations in water level caused by upstream impoundments over time have similarly caused changes in the structure of periphytic algae over time.

Acknowledgements - The authors are grateful to the Nucleus of Research in Limnology, Ichthyology and AquacultureNUPÉLIA, for the infrastructure; to the Long-Term Ecological Research (LTER) site 6, for logistical support; and to CAPESPROEX, for granting the scholarship.

\section{References}

AGOSTINHO, AA., GOMES, LC., VERÍSSIMO, S. and OKADA, EK., 2004. Flood regime, dam regulation and fish in the Upper Paraná River: effects on assemblage attributes, eproduction and recruitment. Reviews in Fish Biology and Fisheries, vol. 14, p. 1119. http://dx.doi.org/10.1007/s11160-004-3551-y

AGOSTINHO, AA., GOMES, LC. and PELICICE, FM., 2007. Impactos dos represamentos: alterações ictiofaunísticas e colonização. In AGOSTINHO, AA., GOMES, LC. and PELICICE FM. (Orgs.). Ecologia e manejo de recursos pesqueiros em reservatórios do brasil. Maringá: Eduem. p. 107-151.

ALGARTE, VM., SIQUEIRA, NS., MURAKAMI, EA. and RODRIGUES, L., 2009. Effects of hydrological regime and connectivity on the interannual variation in taxonomic similarity of periphytic algae. Brazilian journal of biology $=$ Revista brasleira de biologia, vol. 69, no. 2, p. 609-16.

BICUDO, DC., 1990. Considerações sobre metodologias de contagem de algas do perifíton. Acta Limnologica Brasiliensia, vol. 3 , p. 459-475.

BICUDO, CEM. and MENEZES, M., 2006. Gêneros de algas de águas continentais do Brasil. (Chave de identificação e descrições). São Carlos: RIMA. 489 p.

BIGGS, BJE., 1996. Patterns in benthic Algae of Streams. In STEVENSON, RJ., BOTHWELL, ML. and LOWE, RL. (Orgs.). Algal Ecology - Freshwater Benthic Ecosystems. San Diego: Academic Press. p. 31-56.

BLINN, W., SHANNON, JP., STEVENS, LE. and CARDER, JP., 1995. Consequences of Fluctuating Discharge for Lotic Communities. Journal of the North American Benthological Society, vol. 14, p. 233-248. http://dx.doi.org/10.2307/1467776

BUNN, SE. and ARTHINGTON, AH., 2002. Basic principles and ecological consequences of altered flow regimes for aquatic biodiversity. Environmental Management, vol. 30, p. 492-507. PMid:12481916. http://dx.doi.org/10.1007/s00267-002-2737-0

CLARKE, KR. and WARWICK, RM., 2001. Changes in marine communities: an approach to statistical analysis and interpretation. 2nd ed. Plymouth: PRIMER-E. 172 p.

COLLINS, B., WEIN, G. and PHILIPPI, T., 2001. Effects of disturbance intensity and frequency on early old-field succession. Journal of Vegetation Science, vol. 12, p. 721-728. http://dx.doi. org/10.2307/3236913

CONNELL, JH., 1978. Diversity in tropical rain forests and coral reefs. Science, vol. 199, p. 1302-1310. PMid:17840770. http:// dx.doi.org/10.1126/science.199.4335.1302

DAVIDSON, TA., MacKAY, AW., WOLSKI, P., MAZEBEDI, R., MURRAY-HUDSON, M. and TODD, M., 2012. Seasonal and spatial hydrological variability drives aquatic biodiversity in a flood-pulsed, sub-tropical wetland. Freshwater Biology, vol. 57, p. 1253-1265. http://dx.doi.org/10.1111/j.1365-2427.2012.02795.x

FONSECA, IA. and RODRIGUES, L., 2005. Comunidade de algas perifíticas em distintos ambientes da planície de inundação do alto rio Paraná. Acta Scientiarum. Biological Sciences, vol. 27. p. 21-28.

GOTTLIEB, A., RICHARDS, J. and GAISER, E., 2005. Effects of desiccation duration on the community structure and nutrient retention of short and long-hydroperiod Everglades periphyton mats. Aquatic Botany, vol. 82, p. 99-112. http://dx.doi.org/10.1016/j. aquabot.2005.02.012

-, 2006. Comparative study of periphyton community structure in long and short-hydroperiod Everglades marshes. Hydrobiologia, vol. 569, p. 195-207. http://dx.doi.org/10.1007/s10750-006-0132-1 
HAMMER, Ø., HARPER, DAT. and RYAN, PD., 2001. PAST: Paleontological Statistics Software Package for Education and Data Analysis. Palaeontologia Electronica, vol. 4, p. 1-9.

HAWES, I., HOWARD-WILLIAMS, C. and VINCENT, W., 1992. Desiccation and recovery of antarctic cyanobacterial mats. Polar Biology, vol. 12, p. 587-594. http://dx.doi.org/10.1007/BF00236981

HOAGLAND, KD., ROSOWSKI, JR., GRETZ, MR. and ROEMER, SC., 1993. Diatom Extracellular Polymeric Substances: Function, Fine Structure, Chemistry, And Physiology. Journal of Phycology, vol. 29, p. 537-566. http://dx.doi.org/10.1111/j.00223646.1993.00537.x

HOBBS, RJ. and HUENNEKE, LF., 1992. Disturbance, Diversity, and Invasion: Implications for Conservation. Conservation Biology, vol. 6, p. 324-337. http://dx.doi.org/10.1046/j.15231739.1992.06030324.x

JUNK, WJ., BAYLEY, PB. and SPARKS, RE., 1989. The flood pulse concept in river-floodplain systems. Canadian Special Publication of Fisheries and Aquatic Sciences, vol. 106, p. 110-127.

LEANDRINI, J., FONSECA, I. and RODRIGUES, L., 2008. Characterization of habitats based on algal periphyton biomass in the upper Paraná River floodplain, Brazil. Brazilian journal of biology $=$ Revista brasleira de biologia , vol. 68, no. 3, p. 503-9.

LEANDRINI, J. and RODRIGUES, L., 2008. Temporal variation of periphyton biomass in semilotic environments of the upper Paraná River floodplain. Acta Limnologica Brasiliensia, vol. 20, p. 21-28.

LEDGER, ME., HARRIS, RML., ARMITAGE, PD. and MILNER, AM., 2008. Disturbance frequency influences patch dynamics in stream benthic algal communities. Oecologia, vol. 155, p. 809-819. PMid:18193289. http://dx.doi.org/10.1007/s00442-007-0950-5

LEGENDRE, P. and LEGENDRE, L., 1998. Numerical ecology, Developments in environmental modeling. 2nd ed. Amsterdam: Elsevier. 853 p.

LUTTENTON, MR. and BAISDEN, C., 2006. The Relationships Among Disturbance, Substratum Size and Periphyton Community Structure. Hydrobiologia, vol. 561, p. 111-117.

McKNIGHT, DM., TATE, CM., ANDREWS, ED., NIYOGI, DK., COZZETTO, K., WELCH K., LYONS, WB. and CAPONE, DG., 2007. Reactivation of a cryptobiotic stream ecosystem in the McMurdo Dry Valleys, Antarctica: A long-term geomorphological experiment. Geomorphology, vol. 89, p. 186-204. http://dx.doi. org/10.1016/j.geomorph.2006.07.025

McCORMICK, PV., 1996. Resource Competition and Species Coexistence in Freshwater benthic Algal Assemblages. In STEVENSON, RJ., BOTHWELL, ML. and LOWE, RL. (Orgs.). Algal Ecology - Freshwater Benthic Ecosystems. San Diego: Academic Press. p. 229-251.

MIHALJEVIĆ, M. and PFEIFFER, TŽ., 2012. Colonization of periphyton algae in a temperate floodplain lake under a fluctuating spring hydrological regime. Fundamental and Applied Limnology / Archiv für Hydrobiologie, vol. 180, p. 13.
MURAKAMI, EA. and RODRIGUES, L., 2009. Resposta das algas perifíticas às alterações de temperatura e ao enriquecimento artificial de nutrientes em curto período de tempo. Acta Scientiarum. Biological Sciences, vol. 31, p. 273-284.

NEIFF, JJ., 1990. Ideas para la interpretacion ecológica del Parana. Interciencia, vol. 15, p. 424-441

PETERSON, CG., 1987. Influences of flow regime on development and desiccation response of lotic diatom communities. Ecology, vol. 68, p. 946-954. http://dx.doi.org/10.2307/1938366

-, 1996. Response of Benthic Algal Communities to Natural Physical Disturbance. In STEVENSON, RJ., BOTHWELL, ML. and LOWE, RL. (Orgs.). Algal Ecology - Freshwater Benthic Ecosystems. San Diego: Academic Press. p. 375-402.

PETTS, GE., 1984. Impounded rivers: Perspectives for Ecological Managments. Chichester: John Wiley \& Sons. 285 p.

PICKETT, STA. and WHITE, PS., 1985. The ecology of natural disturbance and patch dynamics. Orlando: Academic Press. 387 p.

POFF, NL., ALLAN, JD., BAIN, MB. , KARR, JR., PRESTEGAARD, KL., RICHTER, BD., SPARKS, RE. and STROMBERG, JC., 1997. The Natural Flow Regime. BioScience, vol. 47, no. 11, p. 769-784. http://dx.doi.org/10.2307/1313099

POTTS, M., 1999. Mechanisms of desiccation tolerance in cyanobacteria. European Journal of Phycology, vol. 34, p. 319-328. http://dx.doi.org/10.1080/09670269910001736382

ROBINSON, CT., UEHLINGER, U. and MONAGHAN, MT., 2004. Stream ecosystem response to multiple experimental floods from a reservoir. River Research and Applications, vol. 20, p. 359-377. http://dx.doi.org/10.1002/rra.743

RODRIGUES, L. and BICUDO, DDC., 2001. Similarity among periphyton algal communities in a lentic-lotic gradient of the upper Paraná river floodplain, Brazil. Revista Brasileira de Botânica, vol. 24, p. 235-248. http://dx.doi.org/10.1590/S010084042001000300001

ROS, J., 1979. Práticas de ecologia. Barcelona: Editora Omega. 181 p.

SOUZA FILHO, EE., ROCHA, PC., COMUNELLO, E. and STEVAUX, JC., 2004. Effects of the Porto Primavera Dam on physical environment of the downstream floodplain. In THOMAZ, SM., AGOSTINHO, AA. and HAHN, NS. (Orgs.). The upper Paraná River and its Floodplain: Physical aspects, Ecology and Conservation. Leiden: Backhuys publishers. p. 55-74.

STANLEY, EH., FISHER, SG., JONES, J. and JEREMY, B., 2004. Effects of water loss on primary production: A landscape-scale model. Aquatic Sciences - Research Across Boundaries, vol. 66, p. $130-138$.

UTERMÖHL, H., 1958. Zur Vervollkommnung der quantitativen Phytoplankton. Methodik Mitteilung Internationale Vereinigung fuer Theoretische unde Amgewandte Limnologie, vol. 9, p. 1-38. 